\title{
ALTERNATIVAS LEGAIS PARA A APROPRIAÇÃO DE IMÓVEIS ABANDONADOS: UM ESTUDO DE CASO NO MUNICÍPIO DE SALVADOR/BA
}

LEGAL ALTERNATIVES FOR THE APPROPRIATION OF PROPERTIES ABANDONED: A CASE STUDY IN THE MUNICIPALITY OF SALVADOR / BA

\author{
Bruno Oliveira dos Santos ${ }^{1}$ \\ Edivaldo Machado Boaventura ${ }^{2}$ \\ Renato Barbosa Reis ${ }^{3}$
}

\section{Resumo}

O objetivo do presente artigo é realizar um estudo de caso no município do Salvador/BA sobre o quantitativo de imóveis abandonados em seu território, além de demonstrar os contratempos gerados por tais imóveis à coletividade, sendo que a omissão do poder público em relação a este problema urbano, viola os Princípios da Função Social da Propriedade Privada e da Função Social da Cidade, consagrados expressamente na Constituição Federal Brasileira de 1988 e na legislação ordinária. Um outro objetivo do estudo é demonstrar que existem alternativas legais constantes no ordenamento jurídico brasileiro, as quais legitimam o poder público a se apropriar desses imóveis, com vistas a funcionalizá-los para consecução de diversas políticas públicas. Para tanto, serão utilizadas como fontes da pesquisa as bases de dados dos setores censitários do Instituto Brasileiro de Geografia e Estatística (IBGE) e, como técnicas, a pesquisa bibliográfica, documental e o geoprocessamento. A natureza da pesquisa é qualitativa, por se tratar de análise de conteúdo, sendo o método de abordagem o dedutivo, tendo em vista que foram utilizadas como paradigmas, as categorias de análise constantes na legislação, doutrina e referencial teórico de diversas áreas do conhecimento.

Palavras-chave: Imóveis Abandonados; Função Social da Propriedade Privada; Função Social da Cidade; Alternativas Legais de Apropriação; Poder Público

\section{Abstract}

The objective of the present article is to accomplish a case study in the municipal district of Salvador/BA on the quantitative of abandoned properties in its territory, besides demonstrating the setbacks generated for such properties to the collectivity, and the omission of the public power in relation to this urban problem, violates the Principles of the Social Function of the Deprived Property and of the Social Function of the City, consecrated expressly in the Brazilian Federal Constitution of 1988 and in the ordinary legislation. Another objective of the study is to demonstrate that constant legal alternatives exist in the brazilian legal systems, which legitimate the public power appropriating gave abandoned properties, with views the reuse for

\footnotetext{
1 Mestre em Desenvolvimento Regional e Urbano pela Universidade Salvador (UNIFACS). Docente no Ensino Superior da Universidade Paulista (UNIP). E-mail: brunoadv.72@gmail.com

2 Doutor em Direito pela Universidade Federal da Bahia (UFBA). Professor Emérito e Livre Docente da Universidade Federal da Bahia (UFBA). Professor Titular da Universidade Salvador (UNIFACS). E-mail: edivaldoboaventura@gmail.com

3 Doutor em Biotecnologia em Saúde e Medicina Investigativa pela Fundação Oswaldo Cruz (FIOCRUZ). Professor Titular da Universidade Salvador (UNIFACS). E-mail: georeis @gmail.com
} 
attainment of several public politics. For so much, they will be used as sources of the research the bases of data of the sections of the censuses of the Brazilian Institute of Geography and Statistics (IBGE) and, as techniques, the research bibliographical, documental and the geoprocessing. The kind of the research is qualitative, for treating of content analysis, being the approach method the deductive, tends in view that we were used as paradigms, the analysis categories constant in the legislation, it indoctrinates and theoretical reference of several areas of the knowledge.

Keywords: Abandoned Properties; Social Function of Private Property; Social Function of the City; Legal Appropriation Alternatives; Public Power

\section{INTRODUÇÃO}

Dentre os desdobramentos da questão urbana nas cidades, destaca-se a problemática dos imóveis abandonados. Partindo da concepção de "lugar" de Milton Santos (2009), este é entendido como "o espaço do acontecer solidário ou homólogo, que são os interesses comuns de todas as pessoas de determinada localidade", ou seja, é o espaço do cidadão, onde estão presentes os elementos históricos, culturais, de identidades, dentre outros.

Postas estas premissas, a existência de imóveis abandonados não se coaduna com os interesses coletivos, pelo fato de ensejar inúmeros contratempos à população, tais como, riscos a incolumidade física dos transeuntes, face à iminência de desabamentos; proliferação de endemias, por serem depositários de águas paradas; riscos à segurança pública, por serem utilizados como abrigo de meliantes; reserva para fins de especulação imobiliária, dentre outros.

Sobre a questão da proliferação de endemias, veja-se um estudo de Vladimir Passos de Freitas (2013) a respeito, num artigo intitulado "A Perda da Propriedade Abandonada com Valor Histórico":

O dono tem o dever de ser diligente e conservar o seu bem. Se nele houver construção, deve zelar para que não haja risco de desabamento e até pelo seu aspecto estético. Se for um terreno, deve mantê-lo limpo e não permitir que se transforme em depósito de lixo. Deve, por exemplo, evitar águas paradas que contribuam para a proliferação do mosquito da dengue.

Obviamente que, estando o imóvel abandonado, maior será a incidência de proliferação de mosquitos transmissores de endemias, por ser um depositário de águas paradas. Lucélia Oliveira Almeida (2015, p. 25), num estudo realizado sobre a situação dos imóveis abandonados no centro histórico da cidade de Salvador/BA, constata os riscos ensejados por estes à população, no que diz respeito à segurança pública e incolumidade física dos transeuntes: 


\subsubsection{Imóveis abandonados}

O primeiro levantamento de imóveis com risco de desabamento, realizado pela Defesa Civil no CHS, se deu na década de 1970, resultando no escoramento emergencial daqueles que se encontravam em piores condições. Em 1994, novo levantamento identificou 159 imóveis nesta situação.

O problema é persistente. Em 2006 a CODESAL vistoriou 414 imóveis, dos quais 20\% (82 unidades) foram consideradas de alto risco para moradores e transeuntes. Outros 11\% (46 unidades) representaram perigo não imediato. Estes prédios, muitos em situação precária, também favorecem a atuação de infratores, servindo de abrigo para usuários e traficantes, além de ser um convite à invasão por parte de pessoas em situação de rua.

Além de ensejar inúmeros contratempos à coletividade, a existência de imóveis abandonados no território das cidades afronta o Princípio da Função Social da Propriedade Privada, insculpido no Art. 5 XXII, XXIII da Constituição Federal Brasileira de 1988. Assim, leiase:

Art. 5ㅇ Todos são iguais perante a lei, sem distinção de qualquer natureza, garantindo-se aos brasileiros e aos estrangeiros residentes no País a inviolabilidade do direito à vida, à liberdade, à igualdade, à segurança e à propriedade, nos termos seguintes:

XXII - é garantido o direito de propriedade; XXIII - a propriedade atenderá a sua função social;

Dentre os desdobramentos do Princípio da Função Social da Propriedade Privada, destaca-se o Princípio da Função Social da Cidade, positivado no Art. Art. 182, caput da Constituição Federal Brasileira de 1988:

Art. 182. A política de desenvolvimento urbano, executada pelo Poder Público municipal, conforme diretrizes gerais fixadas em lei, tem por objetivo ordenar o pleno desenvolvimento das funções sociais da cidade e garantir o bem-estar de seus habitantes.

No plano infraconstitucional, a matéria é regulamentada pela Lei 10.257, de 10/07/2001 (Estatuto da Cidade). Assim, leia-se a transcrição literal do Art. $1^{\circ}$ do referido diploma legal:

Art. $1^{\circ} \mathrm{Na}$ execução da política urbana, de que tratam os arts. 182 e 183 da Constituição Federal, será aplicado o previsto nesta Lei.

Parágrafo único. Para todos os efeitos, esta Lei, denominada Estatuto da Cidade, estabelece normas de ordem pública e interesse social que regulam o uso da propriedade urbana em prol do bem coletivo, da segurança e do bem-estar dos cidadãos, bem como do equilíbrio ambiental.

Por sua vez, o Art. $2^{\circ}$ do Estatuto da Cidade estabelece as diretrizes gerais da política urbana, de modo a funcionalizar o território urbano aos interesses da coletividade em diversos aspectos: 
Art. 2ㅇ A política urbana tem por objetivo ordenar o pleno desenvolvimento das funções sociais da cidade e da propriedade urbana, mediante as seguintes diretrizes gerais:

I - garantia do direito a cidades sustentáveis, entendido como o direito à terra urbana, à moradia, ao saneamento ambiental, à infraestrutura urbana, ao transporte e aos serviços públicos, ao trabalho e ao lazer, para as presentes e futuras gerações;

II - gestão democrática por meio da participação da população e de associações representativas dos vários segmentos da comunidade na formulação, execução e acompanhamento de planos, programas e projetos de desenvolvimento urbano;

III - cooperação entre os governos, a iniciativa privada e os demais setores da sociedade no processo de urbanização, em atendimento ao interesse social;

IV - planejamento do desenvolvimento das cidades, da distribuição espacial da população e das atividades econômicas do Município e do território sob sua área de influência, de modo a evitar e corrigir as distorções do crescimento urbano e seus efeitos negativos sobre o meio ambiente;

$\mathrm{V}$ - oferta de equipamentos urbanos e comunitários, transporte e serviços públicos adequados aos interesses e necessidades da população e às características locais.

Assim, procedendo-se à análise dos dispositivos legais supracitados, constata-se que a omissão do poder público, em relação aos imóveis abandonados, afronta os Princípios Constitucionais da Função Social da Propriedade Privada e da Função Social da Cidade. Nesse sentido, considerando o paradigma da legalidade, o que seriam imóveis abandonados? A resposta é encontrada no Art. 5으, § 1으, I do Estatuto da Cidade:

Art. 5으 (...).

$\S 1$ 을 Considera-se subutilizado o imóvel:

I - cujo aproveitamento seja inferior ao mínimo definido no plano diretor ou em legislação dele decorrente.

Portanto, são considerados subutilizados, aqueles imóveis que não têm sua totalidade aproveitada por seus proprietários e possuidores, à luz das diretrizes estabelecidas no Plano Diretor de Desenvolvimento Urbano da Cidade e na legislação ou que estão simplesmente abandonados, que é a ausência de aproveitamento.

Vale ressaltar, que muitos proprietários ou possuidores de imóveis os subutilizam propositadamente para fins de especulação imobiliária, prática esta vedada pelo Estatuto da Cidade, conforme dicção literal do Art. 2ำ, VI, e) do referido diploma legal:

Art. 2ㅇ A política urbana tem por objetivo ordenar o pleno desenvolvimento das funções sociais da cidade e da propriedade urbana, mediante as seguintes diretrizes gerais: (...)

$\mathrm{VI}$ - ordenação e controle do uso do solo, de forma a evitar:

e) a retenção especulativa de imóvel urbano, que resulte na sua subutilização ou não utilização. 
Realizadas as considerações introdutórias, o objetivo do presente trabalho é demonstrar que existem possibilidades legais de intervenção por parte do poder público municipal em imóveis abandonados, de modo a funcionalizá-los para a efetivação diversas políticas públicas de interesse da população, tais como: instalação de creches, escolas, postos de saúde, construções de habitações sociais, dentre outras.

O recorte da presente pesquisa será o município de Salvador/BA. Para tanto, será realizada uma análise espacial e temporal da evolução do quantitativo de imóveis abandonados no referido município no período compreendido entre 1980 a 2017, com base nas informações coletadas na base de dados dos setores censitários do Instituto Brasileiro de Geografia e Estatística (IBGE), além de avaliar as possibilidades de uso dos instrumentos legais para a intervenção do poder público municipal, constantes na Constituição, na legislação federal e municipal, com vistas à minoração do problema, o qual não se circunscreve apenas à cidade de Salvador/BA.

Os métodos utilizados para a operacionalização do trabalho foram a pesquisa bibliográfica e documental, com a análise da legislação vigente e dos referenciais teóricos do direito e de outras áreas do conhecimento, além das informações colhidas na base de dados dos setores censitários do IBGE, o que reforça o caráter interdisciplinar do trabalho.

Também será utilizado o método do geoprocessamento, mediante utilização do programa ArcMap 10 ou ArcGis, por meio do qual será efetuada a triangulação dos dados coletados na base cartográfica do território do município de Salvador/BA, considerando os parâmetros adotados pelo Sistema Informação Geográfica (SIG).

Trata-se de pesquisa qualitativa, por se tratar de análise de conteúdo, considerando as fontes de pesquisa e os procedimentos utilizados. O método de abordagem utilizado foi o dedutivo, tendo em vista que foram utilizadas as categorias de análise constantes na legislação nacional, doutrina jurídica e referencial teórico.

Todavia, antes, serão tratados com maior profundidade conceitos elementares, tais como, o direito à cidade, função social da propriedade privada e função social da cidade, com vistas à delimitação destas categorias, bem como para a obtenção de uma visão mais ampla e contextualizada sobre o tema.

O DIREITO À CIDADE COMO PRESSUPOSTO DA DIGNIDADE HUMANA E CIDADANIA

Revista de Direito da Cidade, vol. 10, no 1. ISSN 2317-7721 pp. 95-132 99 
O presente capítulo tem por objetivo discorrer sobre o direito à cidade em sua acepção ampla, correlacionando-o com o Princípio da Dignidade Humana previsto na Constituição Federal Brasileira, enquanto imperativos éticos fundamentais de efetivação da cidadania, sobretudo no que se refere à funcionalização da cidade em prol dos interesses da coletividade, na perspectiva do paradigma constitucional da função social da propriedade e da cidade.

Para compreender a função social da propriedade e da cidade, primeiramente, é importante compreender o "direito à cidade" em seu aspecto amplo. Confunde-se o direito à cidade apenas ao direito de moradia, quando na verdade este é muito mais abrangente. É funcionalizar a terra e o solo urbano para uma lógica mais inclusiva. Evidente que o mercado, a geração de empregos e as atividades econômicas são muito importantes para a cidade. Todavia, a função mais importante da cidade é propiciar esses meios para o máximo possível de gente e não para o mínimo (ROLNIK, 2016).

Em outras palavras, a cidade em tese, na condição de território administrado por um governo constituído, deve ser funcionalizada ao bem-estar de todos. Nesse sentido, as políticas de planejamento urbano devem ser direcionadas para a promoção da dignidade humana, considerando que o direito à cidade é um direito comum antes mesmo de ser individual, já que esta transformação depende inevitavelmente do exercício de um poder coletivo de moldar o processo de urbanização (HARVEY, 2014). Assim, o componente territorial pressupõe uma instrumentação do território capaz de atribuir a todos os habitantes aqueles bens e serviços indispensáveis.

O simples nascer investe o indivíduo de uma soma inalienável de direitos, apenas pelo fato de ingressar na sociedade humana. Viver, tornar-se um ser no mundo é assumir, com os demais, uma herança moral, que faz de cada qual um portador de prerrogativas sociais, ou seja, direito ao teto, à comida, à educação, à saúde, à proteção contra o frio, a chuva e as intempéries, ao direito ao trabalho, à justiça, à liberdade e a uma existência digna (SANTOS, 2008).

Portanto, o respeito ao indivíduo é a consagração da cidadania. A cidadania é uma lei da sociedade que, sem distinção, atinge a todos e investe cada qual com a força de ser respeitado.

Todavia, para que a cidadania não esteja circunscrita apenas ao plano do discurso, é preciso que esta tenha uma força normativa que confira obrigatoriedade de obediência. Logo, para que a cidadania seja mantida pelas gerações sucessivas, para ter eficácia e ser fonte de direitos, ela deve se inscrever na própria letra das leis, mediante dispositivos institucionais que 
assegurem a fruição das prerrogativas compactuadas entre a Sociedade Civil e o Estado, de modo que a violação de tais prerrogativas deverá ensejar o direito de serem reclamadas e exigíveis de cumprimento pelas instâncias públicas.

Não é por acaso que a Constituição Federal Brasileira de 1988 tem, como princípios fundamentais que orientam quaisquer ações dos poderes públicos em todas as esferas, os Princípios da Cidadania e da Dignidade da Pessoa Humana. Assim, observe-se o inteiro teor do Art. $1^{\circ}$ :

Art. $1^{\circ}$ A República Federativa do Brasil, formada pela união indissolúvel dos Estados e Municípios e do Distrito Federal, constituindo-se em Estado Democrático de Direito e tem como fundamentos:

I- a soberania;

II - a cidadania;

III - a dignidade da pessoa humana;

IV - os valores do trabalho e da livre iniciativa;

$\checkmark$ - o pluralismo político.

Nessa diretriz, o cidadão é uma categoria política que só tem eficácia enquanto categoria jurídica, tendo em vista que o arcabouço jurídico e constitucional constitui uma garantia em prol do indivíduo que lhe garante proteção contra violações de suas prerrogativas, pois consagrada na lei, a cidadania se define igualmente para todos.

Contextualizando com a realidade espacial, mercado e espaço são forças modeladoras da sociedade como um todo. São conjuntos de pontos que asseguram e enquadram diferenciações desigualizadoras, à medida que o espaço não é uma estrutura de aceitação, mas uma estrutura social dinâmica. Logo, as condições "geográficas" são, indubitavelmente, condições sociais, sendo a repartição espacial das classes um fato que se verifica em vários contextos, seja no espaço total de um país ou de uma região específica.

A localização das pessoas no território é determinada, fundamentalmente, pelo produto da combinação entre as forças do mercado imobiliário e decisões de governo, sendo o resultado independente da vontade dos indivíduos atingidos, a exemplos das migrações forçadas pelas circunstâncias econômicas e da supervalorização pelas intervenções do poder público em certas áreas para um melhor êxito da especulação, facilitando uma maior anarquia das localizações e dos fluxos, ensejando um empobrecimento e segregação cumulativas das populações, face à má gestão do território pelo poder público.

Portanto, quando a gestão do espaço é influenciada exclusivamente pelo jogo do mercado, o espaço vivido consagra desigualdades e injustiças, e termina por ser, em maior parte, um espaço sem cidadãos, ou seja, as cidades são geridas para servir à economia e não à sociedade (SANTOS, 2009). 
Para Santos (2009), duas forças influem diretamente na configuração do espaço geográfico, quais sejam, horizontalidades e verticalidades. As horizontalidades correspondem às forças econômicas locais, à ordem local, ao poder local, bem como as suas contiguidades. As verticalidades são as forças ligadas à ordem global, ao capitalismo global. Podem-se citar, como exemplo de verticalidades, grandes corporações que conseguem barganhar com o Estado incentivos fiscais para instalarem unidades produtivas. Assim, para o referido autor, sob a perspectiva do uso do espaço geográfico pela apropriação das verticalidades e horizontalidades, este dever ser compreendido como "território usado" mediado entre o mundo e a sociedade nacional e local.

Todavia, Santos não se limita a compreender o "território usado" apenas sob o aspecto econômico, como também pelos aspectos antropológicos, sociais, financeiros, dentre outros. Nesse sentido, incluindo o processo produtivo e as práticas sociais, a cultura é o que nos dá a consciência de pertencer a um grupo, do qual é o cimento. Logo, a cultura liga as pessoas ao território, atribuindo-Ihe significado. Assim, o território valorado pelos seus habitantes é denominado de lugar, que, para o autor, "é o espaço do acontecer solidário ou homólogo".

Posto isso, não se pode desconsiderar o espaço geográfico como um importante elemento de efetivação da cidadania. Na esteira do que escreveu Lefebvre (1985), o direito à cidade é direito inalienável, de modo a proporcionar uma vida decente para todos. Logo, a cidade deve ser o abrigo de todos os habitantes, de modo a proporciona-lhes bens e serviços mínimos, sem os quais a existência não se torna digna.

Um documento doutrinário importante para compreensão do direito à cidade em sua acepção ampla é A Carta de Atenas sistematizada por Le Corbusier (1933). Trata-se de um documento elaborado por arquitetos e urbanistas renomados em congressos realizados nas décadas de 1930 e 1940, que propunha uma cidade funcionalizada para o conjunto da população, distribuindo entre a população as possibilidades de bem-estar decorrentes dos avanços técnicos.

A Carta de Atenas sintetiza o conteúdo do Urbanismo Racionalista, também chamado de Urbanismo Funcionalista, escola que entendia que as políticas de planejamentos, regional e local urbanos, deveriam submeter a propriedade privada do solo urbano aos interesses coletivos. Posto isso, as cidades deveriam ser organizadas para satisfazer quatro necessidades básicas da população: habitação, trabalho, recreação e circulação (CARTA DE ATENAS, 1941, p. 142). 
Dessa forma, o Estado e a Administração Pública são vistos como elementos neutros voltados para a consecução do bem comum, que, devidamente informados, pautariam sua ação pela suposta racionalidade inerente ao conhecimento técnico e científico, sendo que tal perspectiva deixa de lado tanto o acesso preferencial que as classes dominantes têm ao poder do Estado, quanto aos grupos de poder constituídos no interior do próprio aparelho estatal. Logo, o Estatuto do Solo e um Plano Diretor de Desenvolvimento Urbano são instrumentos dos quais deve se valer o poder público para garantir a justiça social (CARTA DE ATENAS, 1941).

Rebeca Scherer (1986), ao comentar a Carta de Atenas, pontua que o Urbanismo Racionalista, apesar de evidenciar a necessidade de um Estatuto da Terra e a submissão dos interesses individuais aos coletivos, não significa que constitua um ideário revolucionário no sentido de investir contra o sistema capitalista, considerando que, à luz do pensamento de Kant (apud MENDES, 2009), ao homem não se pode atribuir valor (preço), devendo este ser considerado como um fim em si mesmo, o que em outras palavras, significa dizer que o ser humano não pode ser tratado como um mero coadjuvante dos interesses de Estado, mas razão de ser da atuação deste.

Não é por acaso que o ordenamento jurídico brasileiro consagra expressamente a função social da cidade, um desdobramento da função social da propriedade privada, a qual será tratada com maiores detalhes no capítulo a seguir.

\section{ASPECTOS DO DIREITO DE PROPRIEDADE NO ORDENAMENTO BRASILEIRO}

O presente capítulo tem por objetivo discorrer sobre questões jurídicas mais técnicas, no que diz respeito à função social da propriedade privada que, dentre os desdobramentos que interessam ao presente estudo, destacam-se a função social da cidade, decorrendo deste conceito a importância do Plano Diretor de Desenvolvimento Urbano para as cidades, do procedimento de zoneamento, bem como da caracterização jurídica do imóvel abandonado para as finalidades as quais se destinam o presente estudo.

Nessa diretriz, é importante ressaltar que a Constituição Federal de 1988 e o Estatuto da Cidade constituem marcos normativos significativos no ordenamento jurídico brasileiro, pelo fato de consagrarem o direito à cidade com força de lei.

Tecnicamente, o direito de propriedade tem sua definição insculpida no Art. 1228 do Código Civil Brasileiro de 2002, por se tratar de um direito privado. A seguir, a transcrição literal do referido dispositivo legal: 
Art. 1.228. O proprietário tem a faculdade de usar, gozar e dispor da coisa, e o direito de reavê-la do poder de quem quer que injustamente a possua ou detenha.

$\S 1^{\circ} \mathrm{O}$ direito de propriedade deve ser exercido em consonância com as suas finalidades econômicas e sociais e de modo que sejam preservados, de conformidade com o estabelecido em lei especial, a flora, a fauna, as belezas naturais, o equilíbrio ecológico e o patrimônio histórico e artístico, bem como evitada a poluição do ar e das águas.

$\S 2^{\circ}$ São defesos os atos que não trazem ao proprietário qualquer comodidade, ou utilidade, e sejam animados pela intenção de prejudicar outrem.

$\S 3^{\circ}$ O proprietário pode ser privado da coisa, nos casos de desapropriação, por necessidade ou utilidade pública ou interesse social, bem como no de requisição, em caso de perigo público iminente.

$\S 4^{\circ} \mathrm{O}$ proprietário também pode ser privado da coisa se o imóvel reivindicado consistir em extensa área, na posse ininterrupta e de boa-fé, por mais de cinco anos, de considerável número de pessoas, e estas nela houverem realizado, em conjunto ou separadamente, obras e serviços considerados pelo juiz de interesse social e econômico relevante.

$\S 5^{\circ}$ No caso do parágrafo antecedente, o juiz fixará a justa indenização devida ao proprietário; pago o preço, valerá a sentença como título para o registro do imóvel em nome dos possuidores.

Em relação à propriedade do solo, este também encontra disciplinado, em linhas gerais, no Código Civil de 2002, no Art. 1229 e no Art. 1230. Assim, leia-se:

Art. 1.229. A propriedade do solo abrange a do espaço aéreo e subsolo correspondentes, em altura e profundidade úteis ao seu exercício, não podendo o proprietário opor-se a atividades que sejam realizadas, por terceiros, a uma altura ou profundidade tais, que não tenha ele interesse legítimo em impedi-las.

Art. 1.230. A propriedade do solo não abrange as jazidas, minas e demais recursos minerais, os potenciais de energia hidráulica, os monumentos arqueológicos e outros bens referidos por leis especiais.

Parágrafo único. O proprietário do solo tem o direito de explorar os recursos minerais de emprego imediato na construção civil, desde que não submetidos a transformação industrial, obedecido o disposto em lei especial.

Constata-se, portanto, que o próprio Código Civil brasileiro não admite o exercício do direito de propriedade de forma absoluta, à medida que este deverá observar além das finalidades econômicas, as finalidades sociais, o meio ambiente e o patrimônio artístico e cultural, ou seja, é a função social da propriedade privada prevista no Art. $5^{\circ}, \mathrm{XXII}$ e XXIII da Constituição Federal Brasileira citado nas considerações introdutórias.

Posto isso, para uma melhor compreensão da função social da propriedade privada, é preciso uma breve consideração sobre os seus fundamentos históricos e epistemológicos. 


\section{OS FUNDAMENTOS HISTÓRICOS E EPISTEMOLÓGICOS DA FUNÇÃO SOCIAL DA PROPRIEDADE PRIVADA}

Para se entender o delineamento do direito de propriedade tal como se conhece hoje, é preciso que seja realizada uma contextualização histórica, tendo como recorte específico o período de transição do absolutismo monárquico para o Estado de Direito, oriundo da Revolução Francesa no Século XVIII, o qual influenciou de maneira significativa as democracias contemporâneas.

No Estado Monárquico, o rei governava com poderes absolutos, controlando a economia, a justiça, a política e até mesmo a religião dos súditos, e esta era a realidade da França nesse período. Inexistia nessa fase a democracia, pois os trabalhadores não podiam participar das decisões políticas, nem mesmo expor sua opinião sobre as formas de governo, pois os oposicionistas do regime eram presos e condenados à morte. No regime absolutista, a figura do rei personificava a própria figura do Estado.

A sociedade francesa era estratificada e hierarquizada. O topo da pirâmide era formado pela nobreza, o clero, o rei e sua família, condes, duques, marqueses e outros nobres que viviam às custas do que era produzido pela sociedade em geral. A base era formada pelos trabalhadores, camponeses e a burguesia que sustentavam toda a sociedade com o pagamento de altos tributos. Pior era a condição de vida dos desempregados que aumentavam em larga escala nas cidades francesas. A vida dos trabalhadores e camponeses era de extrema miséria e, por isso, desejavam melhorias na qualidade de vida e de trabalho. A burguesia, apesar de sua melhor condição social, desejava mais participação política e maior liberdade econômica (ALCOFORADO, 2015).

A burguesia, então, com vistas à consecução de seus interesses, articulou com as classes populares a Revolução Francesa em 1789, movimento este que culminou com a queda do regime monárquico, instaurando uma nova ordem jurídica, na qual a vontade do monarca foi substituída pela vontade popular representada pela lei (ROUSSEAU, 1999), que sujeitava a todos indistintamente às mesmas normas.

O lema dos revolucionários era consubstanciado em três princípios básicos - liberdade, igualdade e fraternidade, que significam as bases do liberalismo clássico, doutrina política e econômica que prega a separação do Estado da Sociedade Civil (LOCKE, 2006), a defesa da liberdade individual, a limitação do poder do Estado pelo império da lei, a igualdade de todos perante esta, a proteção ao direito de propriedade e ao livre mercado. 
Todavia, apesar de significar um marco histórico para humanidade, a Revolução Francesa, por ter sido uma revolução engendrada pela burguesia, arrebatou o Estado colocando-o a serviço do modo de produção capitalista. Bobbio $(2010$, p. 08) traz uma reflexão interessante a respeito:

Na acepção mais comum dos dois termos, por "liberalismo" entende-se uma determinada concepção de Estado, na qual o Estado tem poderes e funções limitadas, e como tal se contrapõe tanto ao Estado absoluto quanto ao Estado que hoje chamamos de social; por "democracia" entende-se uma das várias formas de governo, em particular aquelas em que o poder não está nas mãos de um só ou de poucos, mas de todos, ou melhor, da maior parte, como tal se contrapondo às formas autocráticas, como a monarquia e a oligarquia. Um Estado liberal não é necessariamente democrático: ao contrário, realiza-se historicamente em sociedades nas quais a participação no governo é bastante restrita, limitada às classes possuidoras.

Em outras palavras, o Estado liberal era alheio às questões de ordem social, pois este, em sua versão mínima, considerava que os atos que ofendessem os direitos individuais limitavam-se apenas àquelas prerrogativas relacionadas ao direito de liberdade e propriedade. No que se refere ao direito de propriedade, dentre os documentos jurídicos mais importantes da época, destaca-se o Código Napoleônico de 1804.

O direito de propriedade, a partir do Código de Napoleão, distingue-se dos direitos políticos, até então lugar especial de alojamento do instituto, desligando-se do poder de jurisdição e afirmando-se como direito civil, direito à utilização econômica da coisa, garantindose ao seu titular a mais ampla liberdade, dentro dos limites de regulamentação legal existentes, o que leva a concluir-se que o paradigma liberal se apropria das instituições políticas e jurídicas para a proteção do mercado (LEAL, 2010).

Para Grau (1998, p. 29a), o mercado é uma instituição jurídica. Antes, porém, o mercado deve ser compreendido, como uma "instituição social", um produto da história, uma criação histórica da humanidade (correspondente a determinadas circunstâncias econômicas, sociais, políticas e ideológicas), que veio a servir e serve aos interesses de alguns, uma "instituição política" destinada a regular e a manter estruturas de poder que asseguram a prevalência dos interesses de certos grupos sobre os interesses de outros grupos sociais. Neste sentido, tanto o Estado como o mercado são espaços ocupados pelo "poder social", entendido como o "poder político" nada mais do que como uma certa forma daquele. Por fim, Grau (1998, p. 30b) arremata que: 
(i) A sociedade capitalista é essencialmente jurídica e nela o Direito atua como mediação específica e necessária das relações de produção que the são próprias;

(ii) Essas relações de produção não poderiam estabelecer-se, nem poderiam reproduzir-se sem a forma do Direito Positivo, Direito posto pelo Estado;

(iii) Este Direito posto pelo Estado surge para disciplinar os mercados, de modo que se pode dizer que ele presta a permitir a fluência da circulação mercantil, para domesticar os determinismos econômicos.

Todavia, no final do século XVIII e no início do século XIX, esse paradigma liberal aos poucos foi se deteriorando por vários motivos, os quais são citados os principais, a saber: 1) os desequilíbrios ocasionados pela ausência de regulação mínima do mercado ensejaram desequilíbrios na livre concorrência ao invés de equilíbrio automático da oferta e da procura; 2) a inexistência de garantias trabalhistas suficientes não ensejou a garantia de uma renda justa; 3 ) a inexistência de regulação de determinadas atividades econômicas ocasionou a concentração de capitais e do capitalismo de grupos, bem como aumento arbitrário e desleal do lucro e dos preços, decorrentes das benesses que o regime da livre iniciativa privada oferecia; 4) a intensidade do desenvolvimento das revoluções científicas e industriais conjuntamente com o cercamento dos campos, aumentaram significativamente a população das cidades e os problemas decorrentes da urbanização desenfreada.

Nesse contexto, os fortes oprimiam os fracos, o que obrigou uma mobilização intensa de setores oprimidos, sobretudo do proletariado, a fim de se exigir uma nova ordem jurídica, social e econômica, a qual obrigasse o Estado a intervir positivamente para aplacar os conflitos oriundos do Estado liberal.

Assim, o homem, livre por natureza, mas sufocado e oprimido pelos graves problemas sociais, foi buscar a proteção do Estado, de quem passou a depender para desenvolver suas virtualidades (BRITO, 1982).

Na lição de Dirley da Cunha Júnior (2004, p. 204), estava instalado o ambiente políticosocial propiciador da intervenção do Estado nas relações socioeconômicas travadas pelo indivíduo. Nasce, nesse contexto, o Estado de Bem-Estar Social ou Welfare State. Vale ressaltar, que as doutrinas socialistas, a partir do século XIX, forneceram um componente ideológico importantíssimo na concepção desse tipo de Estado, considerando que o movimento socialista implantou a ideia de "solidariedade social", que é a responsabilidade de todos pelas carências ou necessidades de qualquer indivíduo ou grupo social.

A emergência da criação desse tipo de Estado interventor ganhou importância de maneira significativa também para solucionar os problemas sociais e econômicos trazidos no 
final da primeira guerra mundial em 1918, e com a crise da bolsa de valores de Nova York de 1929. Durante esse período, destacam-se, como principais documentos jurídicos, a Constituição Alemã de Weimar de 1919 e a Constituição Mexicana de 1917.

Foi justamente nesse contexto que o direito de propriedade adquiriu outra conformação, diferentemente daquela atribuída pelo paradigma liberal. Nesse sentido, a Constituição de Weimar foi um marco significativo, pois influenciou significativamente diversas constituições de países democráticos, inclusive a Constituição Brasileira de 1934, conforme asseverado por Dirley da Cunha Júnior (2004, p. 207):

Não foi, portanto, por acaso que a chamada Constituição de Weimar se tornou a Constituição paradigma do constitucionalismo do primeiro pósguerra e ainda é - como sublinha Raul Machado Horta - "o marco que separa duas épocas históricas: a do constitucionalismo liberal dos séculos XVIII e XIX e a do constitucionalismo social do século XX, que com ela adquiriu expansão universal (...). A constituição de Weimar, efetivamente, representou inquestionável modelo de avanço constitucional na evolução histórica dos direitos fundamentais, com o despontar dos direitos ditos de segunda dimensão, fonte do Estado do bem-estar social na Alemanha e, posteriormente, no Brasil.

A propósito, sob a influência da Constituição de Weimar, a Constituição Brasileira de 1934 foi a primeira que positivou a função social da propriedade privada. Assim, leia-se a transcrição literal do Art. 113, 17):

Art 113 - A Constituição assegura a brasileiros e a estrangeiros residentes no País a inviolabilidade dos direitos concernentes à liberdade, à subsistência, à segurança individual e à propriedade, nos termos seguintes:

17) É garantido o direito de propriedade, que não poderá ser exercido contra o interesse social ou coletivo, na forma que a lei determinar. A desapropriação por necessidade ou utilidade pública far-se-á nos termos da lei, mediante prévia e justa indenização. Em caso de perigo iminente, como guerra ou comoção intestina, poderão as autoridades competentes usar da propriedade particular até onde o bem público o exija, ressalvado o direito à indenização ulterior.

Tal instituto, conforme verificado, foi mantido na atual Constituição Federal Brasileira de 1988 no Art. 5, XXII e XXIII. Mas o que seria a "função social da propriedade"? Tal conceito será explicado sob o prisma do "funcionalismo jurídico", de Norberto Bobbio, no item a seguir.

\section{A FUNÇÃO SOCIAL DA PROPRIEDADE PRIVADA SOB A ÓTICA DO FUNCIONALISMO JURÍDICO}


Partindo da premissa clássica do jurista romano Ulpiano (170 - 228 d.C.), qual seja, "onde está o homem, há sociedade; onde há sociedade, há Direito", constata-se que o Direito é um subsistema social. Mas o que é o Direito? O Direito é um conjunto de normas obrigatórias, que garantem a convivência social, graças ao estabelecimento de limites à ação de cada um de seus membros (REALE, 1977).

Tais normas obrigatórias, também denominadas de normas jurídicas, são as regras e os princípios que disciplinam o mínimo ético, ou seja, os padrões de conduta e os valores indispensáveis para a sobrevivência do grupo social, cujo descumprimento configura uma ilicitude, que é a mais grave forma de infração social cuja sanção é aplicada, única e exclusivamente, pelo Estado.

Para Kelsen (apud BOBBIO, 2010, p. 55), o Direito é uma das bases estruturantes da sociedade, na medida em que corresponde a uma técnica específica de organização social, cuja especificidade consiste no uso dos meios coercitivos para induzir os membros do grupo social a fazer ou não fazer algo. O Direito é um ordenamento coativo. Aquilo que é comum a todos os ordenamentos sociais, que habitualmente são qualificados como jurídicos, é a presença de uma organização, mais ou menos centralizada, para obter dos associados determinados comportamentos, recorrendo-se, em última instância, à força.

Todavia, indaga-se o seguinte: seria o Direito uma mera estrutura estática e meramente sancionatória? Teria o Direito, na qualidade de estruturante social, alguma finalidade? Quem responde tais questionamentos é Norberto Bobbio (2010) em sua clássica obra Da Estrutura à Função, na qual o autor traz a reflexão que a função do direito na sociedade não é mais servir a um determinado fim, mas a de ser um instrumento útil para atingir os mais variados fins, considerando-se que a análise meramente estrutural não se coaduna com a complexidade e a multiplicidade de papéis que assume o Direito numa sociedade moderna, e que este assume inclusive um papel promocional, interferindo, inclusive, na esfera econômica, não apenas em seu aspecto protecionista, mas, sobretudo programático, ao estabelecer diretrizes de orientação da política econômica de determinado Estado. Assim, verifique-se o que Bobbio (2010, p. 77) diz a respeito:

Mesmo depois de termos percebido que o direito não se limita a reprimir, mas de estimular ou promover, podemos continuar a afirmar, como faz Kelsen, que o Direito é um meio e não um fim. Quando chegamos, ainda, a sustentar que o direito é a organização não apenas do poder coativo, mas também do poder econômico, não escapamos de um determinado modo de entender a especificidade do Direito, que consiste precisamente em considerá-lo como forma de organização social. 
Arremata ainda Bobbio, que a função do Direito não é manter a ordem constituída, mas também mudá-la, adaptando-a às mudanças sociais, tanto que existem mecanismos no próprio ordenamento jurídico que prevê alguns procedimentos destinados a regular a produção de normas novas para substituir as velhas, mediante processos legislativos específicos.

Conforme verificado nos itens anteriores, a falência do paradigma liberal e o advento do Estado de Bem-Estar Social ensejaram transformações significativas no ordenamento constitucional de diversos países, inclusive no Brasil, com a promulgação da Constituição Federal de 1934, sobretudo no que se refere ao direito de propriedade.

Posto isso, a função distributiva do direito cresceu enormemente, na medida em que houve um distanciamento do Estado como mediador das relações econômicas, ensejando profundas desigualdades sociais. Assim, sob a perspectiva funcionalista, o Direito é considerado um importante instrumento de efetivação da justiça social.

Para tanto, reiterando o pensamento de Santos (2008), o qual entende que a cidadania é uma categoria política que só tem eficácia enquanto categoria jurídica, é que a Constituição Federal Brasileira de 1988 consagrou expressamente em seu texto a função social da propriedade privada; pois, a depender da forma de apropriação do espaço urbano, este poderá ser um fator determinante de reprodução das desigualdades sociais.

A consagração da função social da propriedade privada no texto constitucional foi uma opção estratégica adotada pelo legislador constituinte, ao passo que a Constituição Federal é a lei maior do Estado, servindo esta de fundamento de validade para a produção das demais normas jurídicas, considerando que estas devem ser produzidas pelo legislador observando-se os princípios por ela consagrados, tanto no aspecto formal (observância dos procedimentos a serem adotados previstos no texto constitucional), quanto material (observância do conteúdo do texto constitucional).

Nesse sentido, o direito de propriedade não deverá ser exercido de forma absoluta, pois este deverá estar funcionalizado na perspectiva social, considerando que a Constituição Federal Brasileira de 1988 adotou a ideologia da Economia Social de Mercado, a qual combina a livre iniciativa com o componente da equidade social, considerando que a livre iniciativa não é sinônimo de liberdade econômica absoluta, anárquica, porém social, e que pode, consequentemente, ser limitada por lei através de instrumentos específicos (GRAU, 1998).

Posto isso, endossa Mello (2010) que o direito de propriedade não se reveste de caráter absoluto, eis que sobre ele pesa grave hipoteca social, a significar que, descumprida a função social que lhe é inerente, legitimar-se-á a intervenção estatal na esfera do domínio privado. 
Sendo assim, é importante citar um pensamento Robert Castel (2010, p. 397) a respeito:

A concepção da propriedade enquanto direito subjetivo desaparece para dar lugar à concepção da propriedade de função social. A propriedade social está no coração do desenvolvimento dos serviços públicos. Estes representam bens coletivos que deveriam permitir uma redução das desigualdades, colocando à disposição de todos, oportunidades comuns.

Dentre os desdobramentos da "função social da propriedade", destaca-se a "função social da cidade", que se coaduna justamente com o direito à cidade em sua acepção ampla. Este, por sua vez, na perspectiva funcionalista do direito, condiciona a propriedade do solo urbano à sua função social, tema este que será tratado no item a seguir.

\section{OS ASPECTOS JURÍDICOS DA PROPRIEDADE URBANA NO BRASIL: A FUNÇÃO SOCIAL DA CIDADE, O PLANO DIREITOR DE DESENVOLVIMENTO URBANO, O PROCEDIMENTO DE ZONEAMENTO E O CONCEITO DE IMÓVEL ABANDONADO À LUZ DO ESTATUTO DA CIDADE}

Realizadas as considerações acerca da função social da propriedade privada sob o aspecto funcionalista de Bobbio, vale deter-se nesse item aos aspectos jurídicos da propriedade urbana no Brasil, tendo como desdobramento a função social da cidade. A função social da cidade, sob o aspecto funcionalista, é justamente direcionar as normas jurídicas que disciplinam a política urbana com vistas à efetivação do direito à cidade em sua perspectiva ampla, conforme pontuado no capítulo quatro do presente trabalho e reforçado por Leal (2010, p. 77):

Podemos destacar neste particular a denominada Reforma Urbana Redistributiva, com grande influência na Constituinte. Seu objeto de intervenção é a propriedade privada da terra, o uso do solo urbano e a participação direta das camadas populares na gestão da cidade. O campo de atuação deste padrão é essencialmente jurídico, caracterizando-se como um eixo de produção de novos direitos sociais.

Em outras palavras, a intervenção do Estado na propriedade privada urbana para o cumprimento de sua função social mitiga o direito absoluto de propriedade do solo urbano, funcionalizando-o de modo a servir aos interesses da coletividade.

Na Constituição Federal de 1988, a política urbana é disciplinada no Art. 182, abaixo transcrito:

Art. 182. A política de desenvolvimento urbano, executada pelo Poder Público municipal, conforme diretrizes gerais fixadas em lei, tem por objetivo ordenar o pleno desenvolvimento das funções sociais da cidade e garantir o bem-estar de seus habitantes. 
$\S 1$ 10 O plano diretor, aprovado pela Câmara Municipal, obrigatório para cidades com mais de vinte mil habitantes, é o instrumento básico da política de desenvolvimento e de expansão urbana.

$\S 2$ ㅇ A propriedade urbana cumpre sua função social quando atende às exigências fundamentais de ordenação da cidade expressas no plano diretor.

§ 3으 As desapropriações de imóveis urbanos serão feitas com prévia e justa indenização em dinheiro.

$\S 4$ É facultado ao Poder Público municipal, mediante lei específica para área incluída no plano diretor, exigir, nos termos da lei federal, do proprietário do solo urbano não edificado, subutilizado ou não utilizado, que promova seu adequado aproveitamento, sob pena, sucessivamente, de:

I - parcelamento ou edificação compulsórios;

II - imposto sobre a propriedade predial e territorial urbana progressivo no tempo;

III - desapropriação com pagamento mediante títulos da dívida pública de emissão previamente aprovada pelo Senado Federal, com prazo de resgate de até dez anos, em parcelas anuais, iguais e sucessivas, assegurados o valor real da indenização e os juros legais.

Pela dicção do mandamento constitucional supracitado, constatou-se que o poder público municipal é o ente federativo que tem a competência para gerir as políticas de desenvolvimento urbano da cidade. Para tanto, utiliza-se do Plano Diretor de Desenvolvimento Urbano como instrumento de planejamento, definição e execução dessas políticas.

O Plano Diretor de Desenvolvimento Urbano é um instrumento de natureza dúplice, pois, juridicamente, é uma lei municipal e, ao mesmo tempo, um instrumento de planejamento e gestão do solo urbano. Conforme verificado no Art. $182 \S 2^{\circ}$ da Constituição Federal supracitado, nas cidades com população maior que vinte mil habitantes é um instrumento obrigatório, devendo ser previamente aprovado pela Câmara Municipal.

Todavia, o Plano Diretor de Desenvolvimento Urbano, antes de ser aprovado pela Câmara Municipal, deverá ser previamente debatido com vários segmentos da sociedade civil por meio de audiências públicas, conforme disposto no Art. 39 e no Art. 40 do Estatuto da Cidade abaixo transcritos:

Art. 39. A propriedade urbana cumpre sua função social quando atende às exigências fundamentais de ordenação da cidade expressas no plano diretor, assegurando o atendimento das necessidades dos cidadãos quanto à qualidade de vida, à justiça social e ao desenvolvimento das atividades econômicas, respeitadas as diretrizes previstas no art. 20 desta Lei.

Art. 40. O plano diretor, aprovado por lei municipal, é o instrumento básico da política de desenvolvimento e expansão urbana.

$\S 100$ plano diretor é parte integrante do processo de planejamento municipal, devendo o plano plurianual, as diretrizes orçamentárias e o orçamento anual incorporar as diretrizes e as prioridades nele contidas. 
§ 20 O plano diretor deverá englobar o território do Município como um todo.

$\S 30 \mathrm{~A}$ lei que instituir o plano diretor deverá ser revista, pelo menos, a cada dez anos.

$\S 40$ No processo de elaboração do plano diretor e na fiscalização de sua implementação, os Poderes Legislativo e Executivo municipais garantirão: I - a promoção de audiências públicas e debates com a participação da população e de associações representativas dos vários segmentos da comunidade;

II - a publicidade quanto aos documentos e informações produzidos;

III - o acesso de qualquer interessado aos documentos e informações produzidos.

$\S 50$ (VETADO).

O processo de planejamento e ordenação do solo urbano através do Plano Diretor de Desenvolvimento Urbano é realizado mediante um procedimento específico denominado de zoneamento.

O zoneamento é um instrumento de intervenção do Estado na ordem econômica e na propriedade, visando ao interesse coletivo, ao passo que, é muito complexa, sobretudo nas grandes cidades, a organização da vida coletiva em vários aspectos (CARDOSO, 2014).

Para tanto é que o plano diretor de uma cidade define a destinação social ou econômica de áreas urbanas, a fim de que o uso e a ocupação do solo sejam utilizados para finalidades diversas, tais como, residenciais, comerciais, industriais, mistas etc.

Assim, o zoneamento determinará os usos conformes, desconformes e tolerados. O uso conforme é aquele indicado para a região onde se situa o imóvel, gerando direito subjetivo para o seu titular. O uso desconforme é incompatível para o local, segundo o que foi definido no zoneamento estabelecido pelo plano diretor e, por isso, não pode ser exercido pelo ocupante do imóvel.

Sendo assim, o imóvel subutilizado, à luz do Art. $5^{\circ}, \S 1^{\circ}$, I do Estatuto da Cidade, transcrito no capítulo introdutório, é aquele cujo aproveitamento seja inferior ao mínimo definido no plano diretor ou em legislação dele decorrente. Nesse sentido, imóvel abandonado é aquele que não é aproveitado pelo proprietário ou possuidor para quaisquer finalidades.

Realizadas as considerações teóricas sobre o direito à cidade, função social da propriedade privada e da função social da sociedade, constata-se que a existência de imóveis abandonados no território das cidades, além de violar princípios jurídicos, não se coaduna com os interesses da população, conforme exposto nas considerações introdutórias. Para tanto, é que existem instrumentos jurídicos específicos que legitimam o poder público a se apropriar de tais imóveis, de modo a funcionalizá-los na perspectiva dos interesses coletivos. 
Posto isso, a proposta do capítulo a seguir é realizar um estudo específico sobre a realidade do município de Salvador/BA, realizando uma análise espacial e temporal da evolução do quantitativo de imóveis abandonados em seu território, no período compreendido entre 1980 a 2017, com base nas informações coletadas na base de dados dos setores censitários do Instituto Brasileiro de Geografia e Estatística (IBGE).

Outro objetivo importante a que se propõe o presente trabalho é avaliar as possibilidades de uso dos instrumentos legais para a intervenção do poder público municipal, constantes na Constituição Federal e na legislação federal e municipal, com vistas à minoração do problema, o qual não se circunscreve apenas ao município em exame, podendo tais iniciativas serem implementadas por outras municipalidades, bem como servirem de orientação para a elaboração, implementação e execução de políticas públicas de desenvolvimento urbano, sob a perspectiva da funcionalização de imóveis abandonados.

Portanto, resta-se inequívoca o caráter instrumental da pesquisa, considerando que os mesmos procedimentos utilizados para a sua materialização, podem servir para a compreensão do mesmo fenômeno em outros municípios brasileiros.

Conforme exposto nas considerações introdutórias, utilizaremos a técnica do geoprocessamento, mediante utilização do programa ArcMap 10 ou ArcGis, por meio do qual será efetuada a triangulação dos dados obtidos pelo IBGE na base cartográfica do território do município de Salvador/BA, considerando os parâmetros adotados pelo Sistema Informação Geográfica (SIG).

A natureza da pesquisa é qualitativa, por se tratar de análise de conteúdo, considerando as fontes de pesquisa e procedimentos utilizados, à luz das categorias de análise ora estudadas, quais sejam, direito à cidade, função social da propriedade privada e função social da cidade.

\section{ANÁLISE TEMPORAL E ESPACIAL DO QUANTITATIVO DE IMÓVEIS ABANDONADOS NA CIDADE DE SALVADOR NO PERÍODO DE 1980 A 2017}

O presente capítulo é a parte empírica do trabalho, no qual será realizada a coleta, análise e interpretação dos dados. Inicialmente, ao realizarmos a coleta dos dados na base de setores censitários do IBGE, nos deparamos com a primeira limitação da pesquisa, tendo em vista que as referidas bases são atualizadas a cada 10 (dez) anos. Posto isso, o censo mais recente do IBGE foi o do ano de 2010, sendo a próxima atualização prevista para o ano de 2020. 
Todavia, eventuais distorções não inviabilizam a pesquisa, tendo em vista que nada impede que esta seja atualizada, à medida em que ocorram atualizações na base de dados do IBGE, o que não impede no presente momento o diagnóstico do problema, além da discussão de implementação de políticas de desenvolvimento urbano nesse sentido, pois estas poderão ser realizadas de forma gradual, servido o presente trabalho como parâmetro para ações futuras, o que não deixa de ser um primeiro passo para a resolução do problema.

Posto isso, os dados coletados para a realização da pesquisa foram aqueles relativos aos censos dos anos de 1980, 1991, 2000 e 2010. Preliminarmente, foi quantificado o número total de domicílios existentes na cidade de Salvador/BA. Segundo o último censo do IBGE do ano 2010, existem 961.976 (novecentos e sessenta e um mil, novecentos e setenta e seis) domicílios na cidade, sendo que desse quantitativo, 77.852 (setenta e sete mil, oitocentos e cinquenta e dois) estão abandonados.

O IBGE qualifica "imóveis abandonados" como "domicílios particulares permanentes não ocupados - vagos" (V008), os quais foram sistematizados na tabela 1 abaixo, a qual consta a evolução do quantitativo de tais imóveis ao longo dos anos, considerando os últimos censos realizados pelo referido órgão:

\section{Evolução do Número de Domicílios Particulares Permanentes Não Ocupados Vagos, Segundo o Subdistrito - Salvador, Bahia - 1980-2010}

\begin{tabular}{|c|c|c|c|c|}
\hline \multirow{2}{*}{ Subdistrito } & \multicolumn{4}{|c|}{ Ano } \\
\cline { 2 - 5 } & 1980 & 1991 & 2000 & 2010 \\
\hline Amaralina & 3.005 & 4.474 & 6.021 & 9.071 \\
\hline Brotas & 2.567 & 3.384 & 4.202 & 5.850 \\
\hline Itapoã & 637 & 1.845 & 3.223 & 5.558 \\
\hline Maré & 42 & 90 & 0 & 307 \\
\hline Mares & 275 & 210 & 0 & 218 \\
\hline Nazaré & 508 & 377 & 367 & 416 \\
\hline Paripe & 1.001 & 2.329 & 3.139 & 4.472 \\
\hline Passo & 182 & 119 & 0 & 104 \\
\hline Penha & 1.687 & 2.070 & 2.595 & 3.344 \\
\hline Periperi & 633 & 1.151 & 1.712 & 2.640 \\
\hline Pirajá & 2.101 & 4.490 & 7.157 & 10.802 \\
\hline Plataforma & 668 & 1.061 & 1.349 & 1.990 \\
\hline Santana & 616 & 439 & 425 & 534 \\
\hline Santo Antônio & 3.652 & 3.925 & 4.503 & 5.842 \\
\hline São Caetano & 2.888 & 4.556 & 6.132 & 8.759 \\
\hline São Cristóvão & 526 & 1.339 & 2.299 & 4.022 \\
\hline
\end{tabular}




\begin{tabular}{|c|c|c|c|c|}
\hline São Pedro & 767 & 594 & 566 & 705 \\
\hline Sé & 690 & 381 & 0 & 270 \\
\hline Valéria & 350 & 2.610 & 12.492 & 6.801 \\
\hline Vitória & 3.619 & 3.975 & 4.587 & 6.147 \\
\hline Total & 26.417 & 39.419 & 60.768 & 77.852 \\
\hline
\end{tabular}

Fonte: Instituto Brasileiro de Geografia e Estatística (IBGE). Censo Demográfico - Dados do Universo. Sistematização, 12/2016.

Analisando a tabela supra, constata-se que no período de 1980 a 1991, o quantitativo de imóveis abandonados aumentou de 26.417 (vinte e seis mil, quatrocentos e dezessete), para 39.419 (trinta e nove mil, quatrocentos de dezenove), representando um aumento de 13.002 (treze mil e dois) imóveis abandonados de uma década para outra.

No períodode 1991 a 2000, o quantitativo de imóveis abandonados em Salvador aumentou de 39.419 (trinta e nove mil, quatrocentos de dezenove), para 60.768 (sessenta mil, setecentos e sessenta e oito), representando um aumento de 21.349 (vinte e um mil, trezentos e quarenta e nove) imóveis abandonados na referida década.

Por fim, no período de 2000 a 2010, o quantitativo de imóveis abandonados aumentou de 60.768 (sessenta mil, setecentos e sessenta e oito) para 77.852 (setenta e sete mil, oitocentos e cinquenta e dois), representando um aumento de 17.084 (dezessete mil e oitenta e quatro) imóveis abandonados na referida década.

Assim, a evolução temporal do quantitativo de imóveis abandonados no período de 1980 a 2010 em Salvador/BA, encontra-se ilustrado no gráfico 1 abaixo:

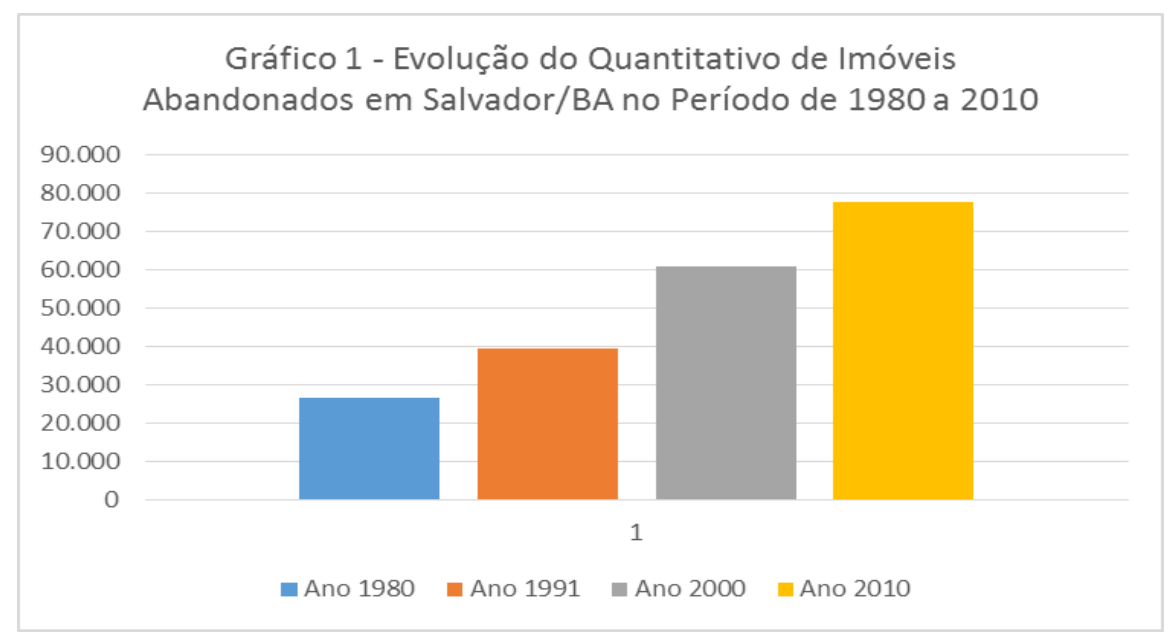

Fonte: Instituto Brasileiro de Geografia e Estatística (IBGE). Censo Demográfico - Dados do Universo. Sistematização, 12/2016.

O IBGE, ao realizar o censo, qualifica o território do município como distrito, e este por sua vez é subdividido em subdistritos. Assim, para o referido órgão, distrito é uma unidade 
administrativa do município, a qual poderá ser subdividida em unidades administrativas menores denominadas subdistritos, os quais englobam bairros, vilas etc.

Assim, georreferenciando os dados da tabela 1 na malha cartográfica do território de Salvador/BA por subdistritos, em relação ao censo de 1980, verifica-se a seguinte realidade:

Mapa 1 - Número de Domicílios Particulares Permanentes Não Ocupados Vagos, segundo a situação por subdistritos - Salvador, Bahia - 1980

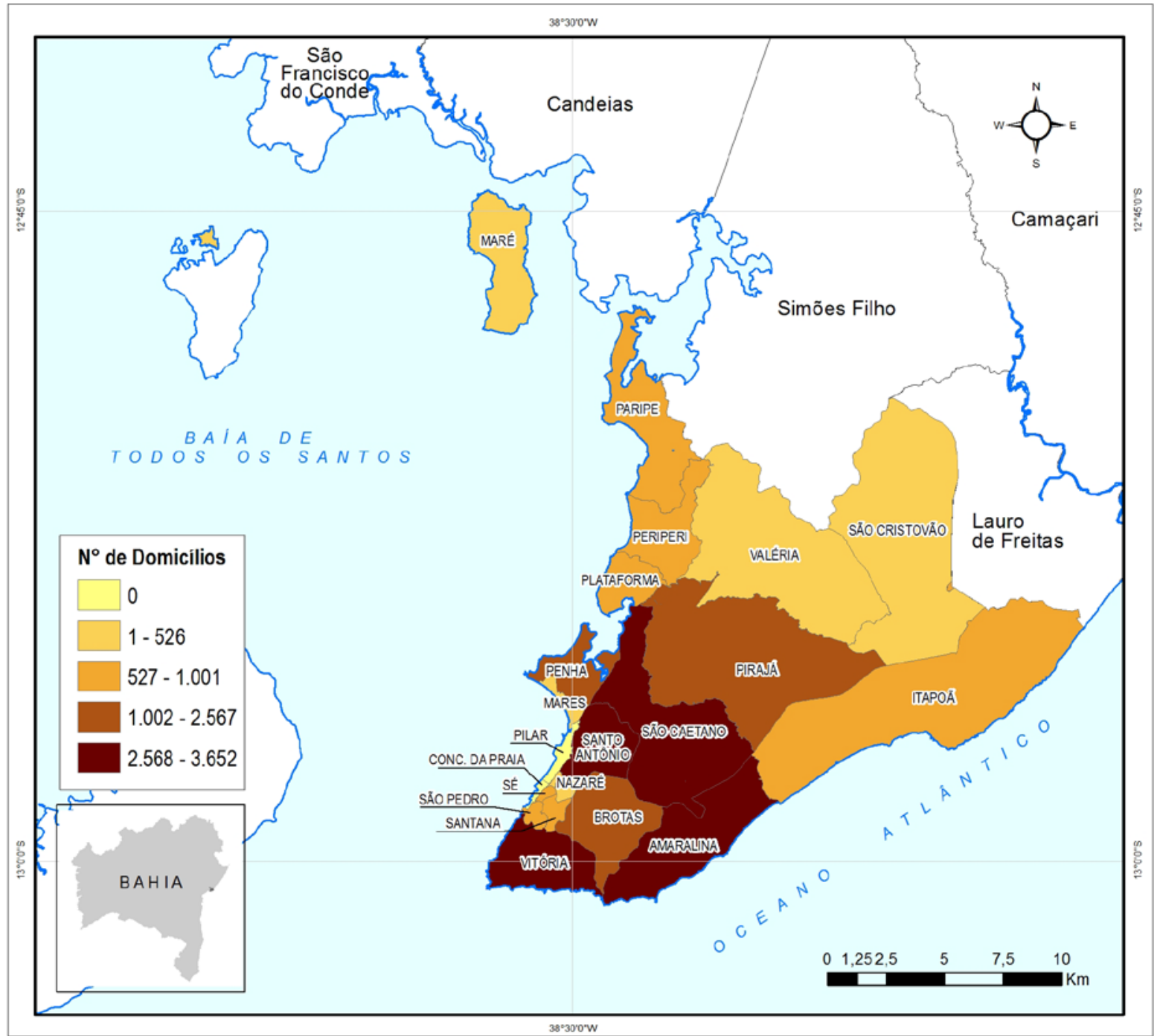

Fonte: Instituto Brasileiro de Geografia e Estatistica (IBGE) Censo Demográfico - Dados do Universo. Sistematização, 12/2016. Mapas Elaborado pelos Autores.

Mapa 2 - Número de Domicílios Particulares Permanentes Não Ocupados Vagos, segundo a situação por subdistritos - Salvador, Bahia - 1991

$38 * 3507 \mathrm{~W}$

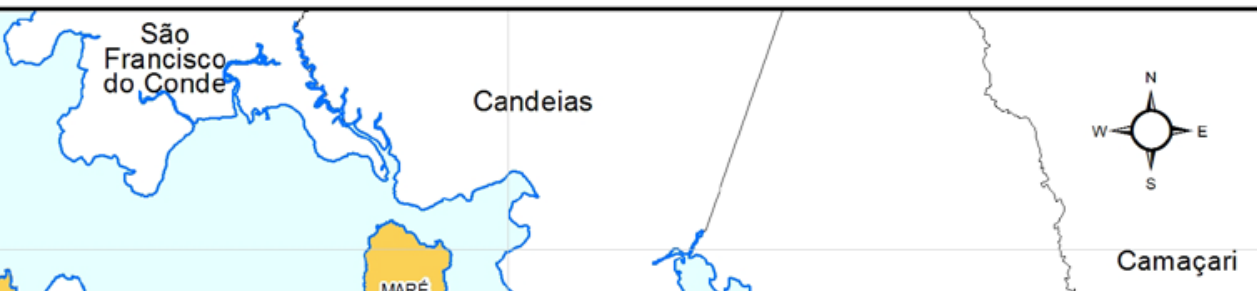


Em relação à base cartográfica do censo de 2000, esta se encontra ilustrada no mapa 3 a seguir:

Mapa 3 - Número de Domicílios Particulares Permanentes Não Ocupados Vagos, segundo a situação por subdistritos - Salvador, Bahia - 2000

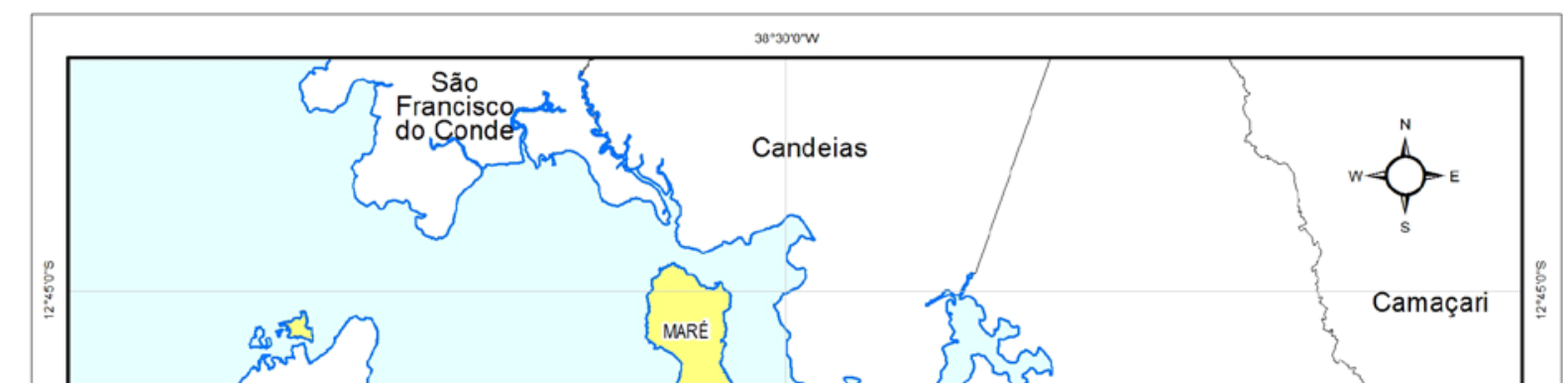


Em relação ao último censo realizado, o de 2010, a base cartográfica deste encontra-se ilustrada no mapa 4 a seguir:

Mapa 4 - Número de Domicílios Particulares Permanentes Não Ocupados Vagos, segundo a situação por subdistritos - Salvador, Bahia - 2010

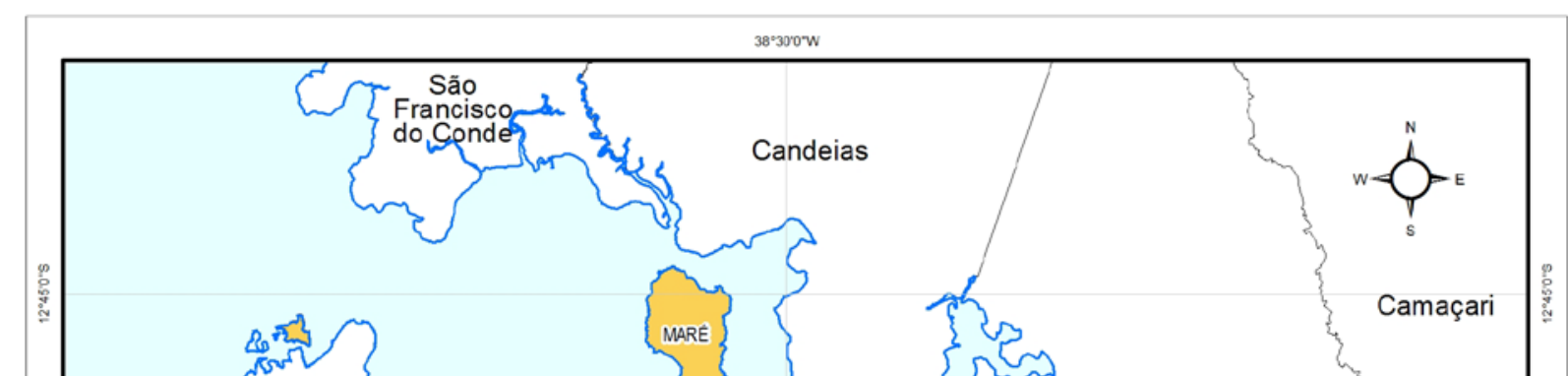


Por fim, foram agrupados os quatro mapas relativos aos censos de 1980, 1991, 2000 e 2010 numa só figura. Assim, sejam vistos:
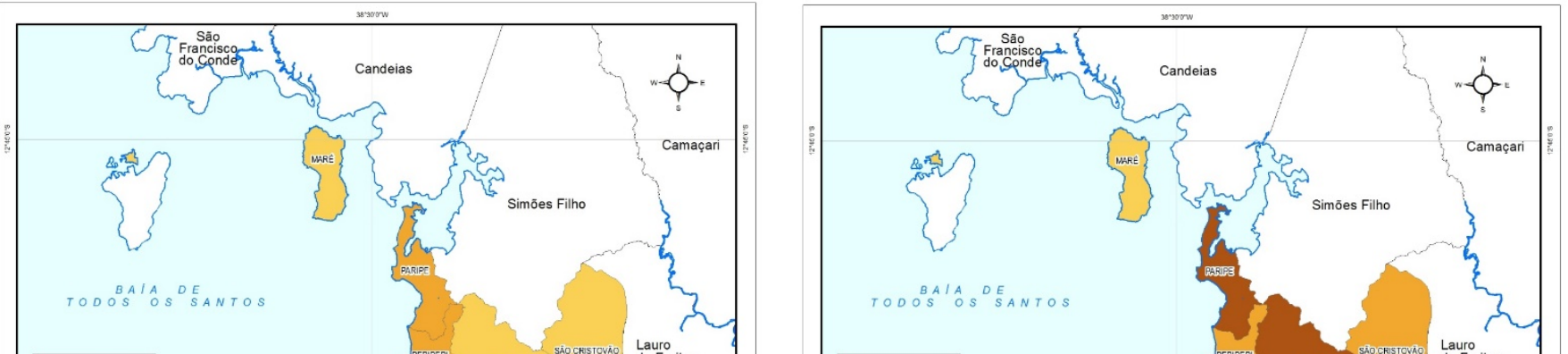

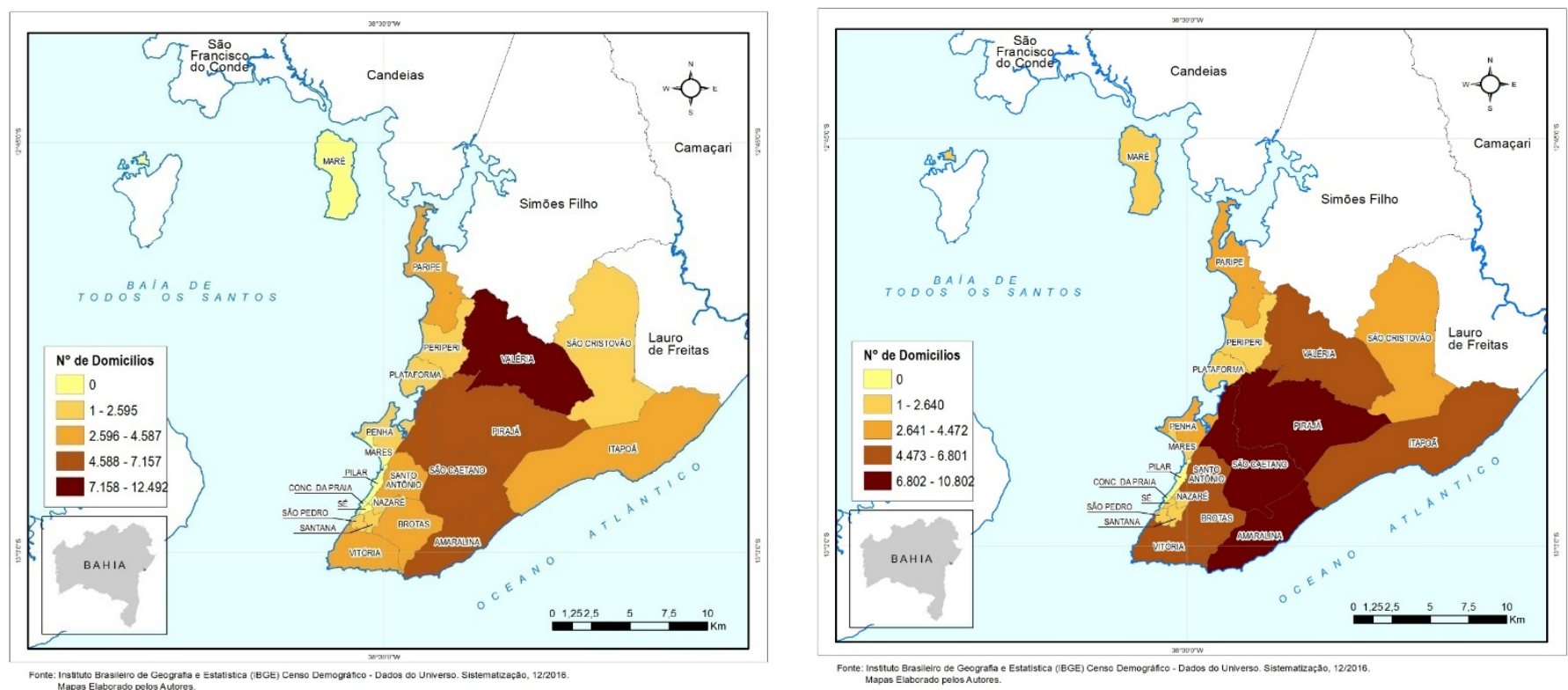

Procedendo-se à análise espacial da evolução do quantitativo de imóveis abandonados por subdistritos no período de 1980 a 2010 no município de Salvador/BA, constatou-se que, no referido período, ocorreu um aumento significativo de imóveis abandonados localizados em sua orla marítima, sobretudo nos subdistritos de Itapoã, Amaralina e Vitória, nos quais estão localizados os bairros nobres da cidade, o que, por via oblíqua, acaba por ensejar uma forte especulação imobiliária em tais localidades, pelo fato de tais imóveis estarem localizados em áreas cujo metro quadrado é o mais valorizado do mercado, o que também pode ser observado em áreas do centro, sobretudo nos subdistritos de Brotas e do Santo Antônio.

Outra constatação é que, no referido período, houve um aumento considerável de imóveis abandonados na área conhecida como subúrbio ferroviário, correspondente àquela que 
vai do subdistrito da Penha até o subdistrito de Paripe, bem como em áreas periféricas localizadas nos subdistritos de Pirajá, São Caetano, Valéria e São Cristóvão, sendo que, nestes, o aumento foi mais expressivo.

Vale ressaltar, que tanto as áreas do subúrbio ferroviário quanto as áreas periféricas ora citadas, são as mais desprovidas de infraestrutura básica, nas quais habita grande parte da população soteropolitana de baixa renda. Portanto, os imóveis abandonados em tais áreas poderiam ser apropriados pelo poder público, a fim de que estes possam ser funcionalizados para políticas de habitação social, instalação de creches, escolas, postos de saúde, dentre outros.

Encerrada a análise espacial dos dados, constata-se que a existência de imóveis abandonados não se coaduna com os interesses da coletividade; pois, além das questões de segurança, saúde pública, incolumidade física dos transeuntes, dentre outras, tais imóveis, quando localizados nas áreas nobres da cidade, ensejam uma forte especulação imobiliária, e nas áreas do subúrbio ferroviário e da periferia, estes poderiam ser funcionalizados para diversas demandas das populações dessas localidades.

Nesse sentido, o capítulo a seguir, tem por objetivo demonstrar que existem instrumentos jurídicos que empoderam o poder público municipal para tanto, bastando apenas vontade política dos gestores em utilizá-los.

\section{ALTERNATIVAS LEGAIS PARA APROPRIAÇÃO DE IMÓVEIS ABANDONADOS PELO PODER PÚBLICO}

O presente capítulo tem por objetivo demonstrar que existem alternativas legais no ordenamento jurídico brasileiro para a apropriação de imóveis abandonados, de modo a funcionalizá-los para o atendimento do interesse público.

Dentre tais alternativas, destaca-se o procedimento da desapropriação. Para Maria Sylvia Zanella Di Pietro (2012), a desapropriação é o procedimento administrativo pelo qual o poder público ou seus delegados mediante prévia declaração de necessidade pública, utilidade pública ou interesse social, impõe ao proprietário a perda de um bem, substituindo-o por uma justa indenização. Assim, o instituto da desapropriação é a prevalência do interesse público sobre o particular a fim de atender necessidades coletivas.

A desapropriação por utilidade pública implica em concretizar ações que terão reflexo de comodidade e utilidade ao coletivo. Assim, não há caráter de urgência, mas sua 
implementação será oportuna e conveniente ao interesse público, cujas hipóteses estão discriminadas no Art. 5o do Decreto-Lei 3365, de 21 de junho de 1941 (Dispõe sobre Desapropriações por Utilidade Pública). Assim, veja-se:

Art. 50 Consideram-se casos de utilidade pública:

a) a segurança nacional;

b) a defesa do Estado;

c) o socorro público em caso de calamidade;

d) a salubridade pública;

e) a criação e melhoramento de centros de população, seu abastecimento regular de meios de subsistência;

f) o aproveitamento industrial das minas e das jazidas minerais, das águas e da energia hidráulica;

g) a assistência pública, as obras de higiene e decoração, casas de saúde, clínicas, estações de clima e fontes medicinais;

h) a exploração ou a conservação dos serviços públicos;

i) a abertura, conservação e melhoramento de vias ou logradouros públicos; a execução de planos de urbanização; o parcelamento do solo, com ou sem edificação, para sua melhor utilização econômica, higiênica ou estética; a construção ou ampliação de distritos industriais

j) o funcionamento dos meios de transporte coletivo;

k) a preservação e conservação dos monumentos históricos e artísticos, isolados ou integrados em conjuntos urbanos ou rurais, bem como as medidas necessárias a manter-lhes e realçar-lhes os aspectos mais valiosos ou característicos e, ainda, a proteção de paisagens e locais particularmente dotados pela natureza;

I) a preservação e a conservação adequada de arquivos, documentos e outros bens moveis de valor histórico ou artístico;

m) a construção de edifícios públicos, monumentos comemorativos e cemitérios;

n) a criação de estádios, aeródromos ou campos de pouso para aeronaves;

o) a reedição ou divulgação de obra ou invento de natureza científica, artística ou literária;

p) os demais casos previstos por leis especiais.

A desapropriação por necessidade pública tem caráter de urgência, ou seja, caso a desapropriação não seja realizada naquele dado momento, os prejuízos poderão ser irreparáveis ao interesse coletivo, pois tratam de situações que surgem quando o poder público se defronta com um problema urgente e inadiável, só removível mediante a transferência do bem particular a seu domínio. Pode ser citado, como exemplo, um imóvel localizado em área de risco e que após chuvas torrenciais, é objeto de deslizamentos, que poderão colocar em risco a vida das pessoas do local e do entorno.

No caso da desapropriação por interesse social, este está diretamente relacionado à justa distribuição da propriedade, destinando-se a prestigiar a concretude das finalidades sociais. Por meio desse instrumento, o poder público almeja conferir um melhor 
aproveitamento, utilização ou produtividade da propriedade em prol da coletividade. A seguir, o artigo 2 da Lei 4.132/62 (Define os casos de desapropriação por interesse social e dispõe sobre sua aplicação), que define as hipóteses de utilização da desapropriação por interesse social e dispõe sobre sua aplicação:

Art. 2o Considera-se de interesse social:

I - O aproveitamento de todo bem improdutivo ou explorado sem correspondência com as necessidades de habitação, trabalho e consumo dos centros de população a que deve ou possa suprir por seu destino econômico;

II - A instalação ou a intensificação das culturas nas áreas em cuja exploração não se obedeça a plano de zoneamento agrícola;

III - o estabelecimento e a manutenção de colônias ou cooperativas de povoamento e trabalho agrícola:

IV - A manutenção de posseiros em terrenos urbanos onde, com a tolerância expressa ou tácita do proprietário, tenham construído sua habilitação, formando núcleos residenciais de mais de 10 (dez) famílias;

$V$ - A construção de casas populares;

VI - As terras e águas suscetíveis de valorização extraordinária, pela conclusão de obras e serviços públicos, notadamente de saneamento, portos, transporte, eletrificação armazenamento de água e irrigação, no caso em que não sejam ditas áreas socialmente aproveitadas;

VII - a proteção do solo e a preservação de cursos e mananciais de água e de reservas florestais;

VIII - a utilização de áreas, locais ou bens que, por suas características, sejam apropriados ao desenvolvimento de atividades turísticas.

Ainda em relação à desapropriação, no que se refere especificamente aos imóveis subutilizados, dentre os quais se enquadram os imóveis abandonados, poderá ser utilizada a desapropriação para fins urbanísticos. Esta se fundamenta no requisito da utilidade pública, visto que é regido pelo princípio da distribuição equitativa da atividade urbanística, considerando os paradigmas do direito à cidade. Este instituto jurídico está disciplinado no 182, $\S 4$ 을 III da Constituição Federal, e no Art. 8o do Estatuto da Cidade. Assim, observe-se o teor do Art. $182, \S 4$ :

Art. 182. A política de desenvolvimento urbano, executada pelo Poder Público municipal, conforme diretrizes gerais fixadas em lei, tem por objetivo ordenar o pleno desenvolvimento das funções sociais da cidade e garantir o bem-estar de seus habitantes. (...)

$\S 4$ o É facultado ao Poder Público municipal, mediante lei específica para área incluída no plano diretor, exigir, nos termos da lei federal, do proprietário do solo urbano não edificado, subutilizado ou não utilizado, que promova seu adequado aproveitamento, sob pena, sucessivamente, de:

I - parcelamento ou edificação compulsórios;

II - imposto sobre a propriedade predial e territorial urbana progressivo no tempo; 
III - desapropriação com pagamento mediante títulos da dívida pública de emissão previamente aprovada pelo Senado Federal, com prazo de resgate de até dez anos, em parcelas anuais, iguais e sucessivas, assegurados o valor real da indenização e os juros legais.

Observe-se também o teor do Art. 8o do Estatuto da Cidade:

Art. $8^{\circ}$ Decorridos cinco anos de cobrança do IPTU progressivo sem que o proprietário tenha cumprido a obrigação de parcelamento, edificação ou utilização, o Município poderá proceder à desapropriação do imóvel, com pagamento em títulos da dívida pública.

$\S 1$ O Os títulos da dívida pública terão prévia aprovação pelo Senado Federal e serão resgatados no prazo de até dez anos, em prestações anuais, iguais e sucessivas, assegurados o valor real da indenização e os juros legais de seis por cento ao ano.

$\S 2$ ○ O valor real da indenização:

I - Refletirá o valor da base de cálculo do IPTU, descontado o montante incorporado em função de obras realizadas pelo Poder Público na área onde o mesmo se localiza após a notificação de que trata o $\S 2^{\circ}$ do art. $5^{\circ}$ desta Lei;

II - Não computará expectativas de ganhos, lucros cessantes e juros compensatórios.

$\S 3$ 응 Os títulos de que trata este artigo não terão poder liberatório para pagamento de tributos.

$\S 4$ ○ O Município procederá ao adequado aproveitamento do imóvel no prazo máximo de cinco anos, contado a partir da sua incorporação ao patrimônio público.

$\S 5$ ○ 0 aproveitamento do imóvel poderá ser efetivado diretamente pelo Poder Público ou por meio de alienação ou concessão a terceiros, observando-se, nesses casos, o devido procedimento licitatório.

$\S 6$ o Ficam mantidas para o adquirente de imóvel nos termos do $\S 5$ as mesmas obrigações de parcelamento, edificação ou utilização previstas no art. 5o desta Lei.

Em regra, as demais desapropriações de imóveis urbanos são realizadas com prévia e justa indenização em dinheiro. No entanto, a desapropriação para fins urbanísticos, conforme verificado nos dispositivos legais supracitados, difere das demais pelo fato de caracterizar-se como um instrumento de realização da política do solo urbano em função da execução do planejamento urbanístico. Assim, não é apenas uma forma de transferência de propriedade do particular para o Poder Público, é, sobretudo, uma forma de utilizar os bens expropriados para atender a função social no meio urbano.

Outro aspecto que a diferencia das demais, é que esta é de competência exclusiva do Município, sendo a indenização paga ao particular mediante títulos da dívida pública de emissão previamente aprovada pelo Senado Federal, com prazo de resgate de até 10 (dez) anos, em parcelas anuais, iguais e sucessivas, assegurados o valor real da indenização e os juros legais.

Ocorre que, no decorrer da pesquisa, constatou-se que existe uma lei municipal de Salvador/BA, qual seja, Lei $N^{\circ}$ 8.553, de 28 de janeiro de 2014, a qual prevê o instituto jurídico 
da arrecadação e encampação de imóveis urbanos abandonados. Originalmente, tal instituto jurídico encontra-se previsto no Art. 1.276 do Código Civil Brasileiro de 2002. Assim, leia-se:

Art. 1.276. O imóvel urbano que o proprietário abandonar, com a intenção de não mais o conservar em seu patrimônio, e que se não encontrar na posse de outrem, poderá ser arrecadado, como bem vago, e passar, três anos depois, à propriedade do Município ou à do Distrito Federal, se se achar nas respectivas circunscrições.

$\S 10$ O imóvel situado na zona rural, abandonado nas mesmas circunstâncias, poderá ser arrecadado, como bem vago, e passar, três anos depois, à propriedade da União, onde quer que ele se localize.

$\S 20$ Presumir-se-á de modo absoluto a intenção a que se refere este artigo, quando, cessados os atos de posse, deixar o proprietário de satisfazer os ônus fiscais.

Por sua vez, o Art. $1^{\circ}$ da Lei $n^{\circ} 8.553$, de 28 de janeiro de 2014, reproduz o texto do dispositivo legal supracitado. Assim, leia-se:

Art. $1^{\circ}$ Os imóveis urbanos abandonados, cujos proprietários não possuam a intenção de conservá-lo em seu patrimônio e que não se encontrem na posse de outrem, ficam sujeitos à arrecadação e à encampação pelo Município de Salvador, na condição de bem vago.

$\S 1^{\circ} \mathrm{A}$ ausência da intenção referida no caput deste artigo será presumida quando o proprietário, cessada a sua posse sobre o imóvel, não adimplir com os decorrentes ônus fiscais.

$\S 2^{\circ} \mathrm{O}$ imóvel abandonado, localizado em zona urbana do Município de Salvador, será considerado vago e passará ao Município, nos termos do art. 1.276 do Código Civil (Lei Federal $n^{\circ}$ 10.406, de 10 de janeiro de 2002).

O Art. $4^{\circ}$ da referida lei delimita juridicamente o conceito de imóvel abandonado.

Assim, observe-se:

Art. $4^{\circ} \mathrm{O}$ abandono do imóvel configura-se quando o proprietário tem conduta juridicamente definida como de manifestação de vontade, assim entendida a de não mais o conservar em seu patrimônio, de modo a torná-lo um bem vago.

Parágrafo Único. O Município de Salvador adquire a propriedade do bem vago 03 (três) anos depois de o imóvel ser assim considerado.

Nessa diretriz, o dispositivo legal supracitado é claro ao dispor que o imóvel abandonado é considerado vago, e que o município só adquire a propriedade deste após o período de 03 (três) anos depois de assim o ser considerado.

Todavia, este reconhecimento não se dá de forma automática, pois faz-se necessária a observância de um processo administrativo regular para tanto, o qual seja assegurado ao proprietário ou possuidor do bem, o direito do contraditório e da ampla defesa, ou seja, o direito de ser notificado pela municipalidade sobre a existência de um processo administrativo de arrecadação do bem e de apresentação de sua respectiva defesa. 
Nesse sentido, o processo administrativo de arrecadação poderá ser instaurado de ofício pelo Poder Público Municipal, ou seja, quando os agentes públicos municipais têm conhecimento da existência de um imóvel abandonado, ou por denúncia de um particular.

As disposições relativas ao processo administrativo de arrecadação estão previstas no Art. $2^{\circ}$ da referida lei. Assim, observe-se:

Art. $2^{\circ} \mathrm{A}$ arrecadação de que trata esta Lei terá início de ofício ou por denúncia e prosseguirá com:

I - A realização de atos de diligência, mediante elaboração de relatório circunstanciado contendo a descrição das condições do imóvel;

II - A confirmação da situação de abandono, a lavratura do respectivo Auto de Infração e a instrução de processo administrativo;

$\S 1^{\circ} \mathrm{O}$ processo administrativo conterá os seguintes documentos:

Requerimento ou denúncia que motivou a diligência;

Certidão imobiliária atualizada;

Termo declaratório dos ocupantes de imóveis contíguos, quando houver; Certidão positiva de ônus fiscais;

Cópias das publicações do Decreto de Arrecadação;

Outras provas do estado de abandono do imóvel, quando houver;

$\S 2^{\circ} \mathrm{O}$ procedimento poderá ser instaurado a partir de denúncia, inclusive na hipótese de dano infecto resultante de omissão do proprietário do imóvel, nos termos do art. 1.280 do Código Civil.

$\S 3^{\circ} \mathrm{O}$ Poder Executivo adotará os procedimentos estabelecidos nesta Lei, inclusive os judiciais que couberem, para passar ao domínio público o imóvel arrecadado, ressalvada a hipótese da presunção absoluta de abandono a que se refere o art. $5^{\circ}$ desta Lei e seus parágrafos, dando-lhe, em qualquer hipótese, destinação, no interesse público justificado em Decreto, tal como previsto nesta Lei, inclusive mediante permuta e alienação.

Outro aspecto relevante da lei é que esta prevê a presunção absoluta de abandono do imóvel, o que torna o processo de arrecadação mais célere, ao passo que, observada tal condição, não precisará o município observar o prazo de 3 (três) anos após a finalização do respectivo processo administrativo para que o bem seja declarado vago.

Nesse sentido, a presunção absoluta de abandono do imóvel é considerada na hipótese de cessados os atos de posse, quando o possuidor ou proprietário deixa de satisfazer os ônus fiscais decorrentes da posse ou propriedade do bem, situação que será constatada com a inscrição dos respectivos débitos na dívida ativa do município e com a respectiva abertura de processo administrativo fiscal, no qual o possuidor ou proprietário do imóvel resta-se revel (situação em que o indivíduo não apresenta defesa quando devidamente notificado), ou quando inadimplente com as obrigações tributárias, sendo tal confirmação de abandono irreversível, ainda que o inadimplente proceda ao pagamento dos tributos. Assim, observe-se o quanto disposto no Art. $5^{\circ}$ da Lei: 
Art. $5^{\circ}$ É bem vago, para os efeitos desta Lei, o imóvel urbano que:

I- Estiver abandonado pelo proprietário; e

II - Não estiver na posse de outrem.

$\S 1^{\circ}$ Presumir-se-á, de modo absoluto, a intenção do proprietário de não mais conservar o imóvel em seu patrimônio quando, cessados os atos de posse, deixar de satisfazer os ônus ficais, mediante o não cumprimento de prestação pecuniária compulsória correspondente a um dos tributos imobiliários que tenham o imóvel como elemento material da hipótese do fato gerador.

$\S 2^{\circ}$ Confirmar-se-á a situação de abandono, na hipótese do $\S 1^{\circ}$ deste artigo, pela lavratura do Auto de Infração, seguida da instrução do processo administrativo fiscal, cuja finalização ocorrer com a revelia ou com a inadimplência do contribuinte proprietário do imóvel.

$\S 3^{\circ} \mathrm{A}$ presunção absoluta opera a aquisição da propriedade do bem vago, independentemente do interstício temporal referido no Parágrafo Único do Art. $4^{\circ}$ desta Lei.

$\S 4^{\circ} \mathrm{A}$ confirmação do abandono, nos termos do $\S 1^{\circ}$ deste artigo, é irreversível, ainda que o inadimplente cumpra a prestação pecuniária compulsória.

Por fim, o Art. 11 da referida lei direciona para quais políticas públicas os imóveis arrecadados serão funcionalizados. Assim, pois:

Art. 11 Os imóveis encampados com base nesta Lei serão destinados, prioritariamente, a programas habitacionais, à prestação de serviços públicos, no fomento ao Turismo no Município do Salvador, ou serão objeto de concessão de direito real de uso a entidades civis que, comprovadamente, tenham fins filantrópicos, assistenciais, educativos, esportivos ou outros, a interesse do Município.

\section{CONCLUSÕES}

Ante o exposto, concluímos que a existência de imóveis abandonados não se coaduna com os interesses coletivos, pelo fato de ensejar inúmeros contratempos à população, além de violar os princípios jurídicos da Função Social da Propriedade Privada e da Função Social da Cidade.

No caso específico do município de Salvador/BA, constata-se que o quantitativo de imóveis abandonados aumentou significativamente durante o período de 1980 a 2010, passando do quantitativo de 26.417 (vinte e seis mil, quatrocentos e dezessete) no ano de 1980 para 77.852 (setenta e sete mil, oitocentos e cinquenta e dois) no ano de 2010, representando um aumento de cerca de 51.435 (cinquenta e um mil, quatrocentos e trina e cinco) imóveis abandonados num intervalo de trinta anos. Por conseguinte, constata-se que não existiu ao longo desse período uma política municipal para a minoração do problema. 
Todavia, a edição da Lei Municipal N 8.553, de 28 de janeiro de 2014, representou um avanço institucional importantíssimo nesse sentido, cuja eficácia será verificada na próxima atualização do censo do IBGE prevista para o ano de 2020.

Outrossim, após a análise espacial dos referidos dados na base cartográfica do município de Salvador/BA relativos ao período em epígrafe, constata-se um aumento significativo de imóveis abandonados localizados na orla marítima do município, sobretudo nos subdistritos de Itapoã, Amaralina e Vitória, nos quais estão localizados os bairros mais nobres da cidade, o que, por via oblíqua, acaba por ensejar uma forte especulação imobiliária em tais localidades, pelo fato de tais imóveis estarem localizados em áreas cujo metro quadrado é o mais valorizado do mercado, o que também pode ser observado em áreas do centro, sobretudo nos subdistritos de Brotas e do Santo Antônio.

Outra constatação é que, no referido período, houve um aumento considerável de imóveis abandonados na área conhecida como subúrbio ferroviário, correspondente àquela que vai do subdistrito da Penha até o subdistrito de Paripe, bem como em áreas periféricas localizadas nos subdistritos de Pirajá, São Caetano, Valéria e São Cristóvão, sendo que, nestes, o aumento foi mais expressivo, ressaltando que em tais áreas habita grande parte da população soteropolitana de baixa renda. Assim, tais imóveis poderiam ser apropriados pelo poder público para a implementação de políticas de habitação social, instalação de creches, escolas, postos de saúde, dentre outros.

Por fim, considerando a perspectiva funcionalista do Direito de Bobbio, constata-se que no ordenamento jurídico brasileiro existem instrumentos legais que legitimam o Estado a se apropriar desses imóveis, com vistas a direcioná-los para a execução de políticas públicas de interesse da população. Dentre os referidos instrumentos, destacam-se as desapropriações por utilidade ou necessidade pública, a desapropriação para fins urbanísticos e o instituto da arrecadação gratuita, sendo esta, conforme verificado, a menos onerosa para os cofres públicos.

Todavia, a existência de um arcabouço legal por si só não será suficiente para a resolução do problema, se não existir uma intencionalidade política clara por parte dos agentes públicos de efetivar tais ações.

\section{REFERÊNCIAS}

ALCOFORADO, Fernando. Projeto de Novo Modelo de Sociedade a Ser Edificado no Futuro. Revista do Instituto Geográfico e Histórico da Bahia, Salvador, v. 110, p. 127-148, jan./dez. 2015. 
ALMEIDA, Lucélia Oliveira. A Influência dos Pressupostos da Teoria da Ecologia Criminal da Escola de Chicago para a Elaboração das Ações de Segurança Pública para o Centro Histórico de Salvador. 2015. 36 f. Dissertação (Mestrado) - Segurança Pública, Justiça e Cidadania. Universidade Federal da Bahia - UFBA, Salvador, 2015.

BOBBIO, Norberto. Da Estrutura à Função. Novos Estudos da Teoria do Direito. 3. ed. São Paulo: Editora Manole, 2010.

BRASIL. Constituição (1988). Constituição da República Federativa do Brasil. Brasília, DF: Senado Federal, 1988.

Constituição (1934). Constituição da República Federativa do Brasil. Rio de Janeiro, RJ: Assembleia Nacional Constituinte, 1934.

Lei $n^{\circ}$ 10.257, de 10 de julho de 2001. Regulamenta os arts. 182 e 183 da Constituição Federal, Estabelece Diretrizes Gerais da Política Urbana e dá Outras Providências. Diário Oficial da República Federativa do Brasil, Brasília, DF, 8 jul. 2001. Disponível em: <www.planalto.gov.br/ccivil_03/leis/LEIS_2001/L10257.htm>. Acesso em: 22 jul. 2015.

Lei $n^{\circ}$ 10.406, de 10 de janeiro de 2002. Institui o Código Civil. Diário Oficial da República Federativa do Brasil, Brasília, DF, 10 jan. 2002. Disponível em: <www.planalto.gov.br/ccivil_03/leis/2002/L10406.htm>. Acesso em: 22 jul. 2015.

Decreto-Lei 3.365, de 21 de junho de 1941. Dispõe sobre Desapropriações por Utilidade Pública. Diário Oficial da República Federativa do Brasil, Rio de Janeiro, RJ, 21 jun. 1941. Disponível em: <www.planalto.gov.br/ccivil_03/Decreto-lei/Del3365.htm>. Acesso em: 22 jul. 2015.

Lei 4.132, de 10 de setembro de 1962. Define os casos de desapropriação por interesse social e dispõe sobre sua aplicação. Diário Oficial da República Federativa do Brasil, Brasília, DF, 10 set. 1962. Disponível em: <www.planalto.gov.br/ccivil_03/leis/L4132.htm>. Acesso em: 22 jul. 2015.

BRITO, Edvaldo. Reflexos Jurídicos da Atuação do Estado no Domínio Econômico: Desenvolvimento Econômico e Bem-Estar Social. São Paulo: Saraiva, 1982.

CARDOSO, Fernanda Lousada. Direito Urbanístico. 3. ed. Salvador: Juspodivm, 2014.

CASTEL, Robert. As Metamorfoses da Questão Social. 5. ed. Petrópolis: Vozes, 2010.

CORBUSIER, Le; GIRAUDOUX, Jean. A Carta de Atenas. São Paulo: Hucitec, 1993.

CUNHA JÚNIOR, Dirley Da. Controle Judicial das Omissões do Poder Público. 2. ed. São Paulo: Saraiva, 2004.

DI PIETRO, Maria Sylvia Zanella. Direito administrativo. 23. ed. São Paulo: Atlas, 2010.

FREITAS, Vladimir Passos de. A Perda da Propriedade Abandonada com Valor Histórico. MPMG Jurídico, 2013.

GRAU, Eros Roberto. A Ordem Econômica na Constituição de 1988. 4. ed. São Paulo: Malheiros Editores, 1998.

HARVEY, David. A Condição Pós-Moderna. 25. ed. Rio de Janeiro: Edições Loyola, 2014. 
A Produção Capitalista do Espaço. 2. ed. São Paulo: Annablume, 2005.

INSTITUTO BRASILEIRO DE GEOGRAFIA E ESTATÍSTICA - IBGE. Sinopse de Setores do IBGE. Disponível em: <www.censo2010.ibge.gov.br/sinopseporsetores>. Acesso em: 11 nov. 2016. Informações Sobre o Município de Salvador/BA. Disponível em: <http://www.cidades.ibge.gov.br/v3/cidades/municipio/2927408>. Acesso em: 11 nov. 2016. Base de Informações do Censo Demográfico 2010: Resultados da Sinopse por Setor Censitário. Rio de Janeiro: IBGE, 2011.

Base de Informações do Censo Demográfico 2010: Resultados por Universo por Setor Censitário. Rio de Janeiro: IBGE, 2011.

SALVADOR. Lei n ${ }^{\circ}$ 8.553, de 28 de janeiro de 2014. Dispõe sobre a Arrecadação e a Encampação de Imóveis Urbanos Abandonados no Município de Salvador e dá outras providências. Diário Oficial do Município de Salvador/BA, Salvador, BA, 28 jan. 2014. Disponível em: <https://www.legisweb.com.br/legislacao/?id=265052 >. Acesso em: 17 jan. 2017.

SANTOS, Milton. Pensando o Espaço do Homem. 5. ed. São Paulo: Edusp, 2009.

Técnica, Espaço, Tempo: Globalização e Meio Técnico-Científico Informacional. 4. ed. São Paulo: Edusp, 2008.

Espaço do Cidadão. 4. ed. Petrópolis: Vozes, 2008.

SCHERER, Rebeca. Notas Sobre Planejamento e Método. FAU, 1995.

LEAL, Roberto Gesta. Função Social da Propriedade e da Cidade no Brasil: Aspectos Jurídicos e Políticos. 2. ed. Porto Alegre: Livraria do Advogado, 2010

LEFEBVRE, Henri. O Direito à Cidade. 3. ed. São Paulo: Moraes Ltda, 1985.

LOCKE, John. Segundo Tratado Sobre o Governo Civil e Outros Escritos: Ensaio Sobre a Origem, os Limites e os Fins Verdadeiros do Governo Civil. 9. ed. Petrópolis: Vozes, 2006.

MELLO. Celso Antônio Bandeira de. O Conteúdo Jurídico do Princípio da Igualdade. 3. ed. São Paulo: Malheiros, 2010.

Curso de Direito Administrativo. 25. ed. São Paulo: Malheiros, 2010.

MENDES, Gilmar Ferreira; COELHO, Inocêncio Martires; BRANCO, Paulo Gustavo Gonet. Curso de Direito Constitucional. 3. ed. São Paulo: Saraiva, 2008.

ROCHA, Cézar Henrique Barra Rocha. Geoprocessamento: Tecnologia Transdisciplinar. 3. ed. Juiz de Fora: UFJF, 2007.

ROLNIK, Raquel. Guerra dos Lugares: A Colonização da Terra e da Moradia na Era das Finanças. São Paulo: Travessa, 2016.

ROUSSEAU, Jean Jaques. Do Contrato Social. Rio de Janeiro: Abril, 1999.

Trabalho enviado em 16 de julho de 2017.

Aceito em 12 de novembro de 2017. 
vol. 10, ํㅜ 1. ISSN 2317-7721

DOI: $10.12957 /$ rdc.2018.29621 